\title{
Chapter 3 Work experience and VET: insights from the connective typology and the recontextualisation model
}

\author{
David Guile, Institute of Education, University College London, United Kingdom
}

\begin{abstract}
The chapter compares two models of work experience - connective typology of work experience and recontextualisation of knowledge model - and uses the term work experience to refer to the way that young people enrolled on both school- and apprenticeship-based VET learn to relate their experience of education as represented by the acquisition of domain knowledge and their experience of work as represented by occupational values, skill and knowledge, to one another. The common link between the two models is that they accept the existence of a mediated relationship between education and work. The former explores this relationship from a boundary crossing perspective, focusing on learners' movement between education and work and identifies the outcomes associated with different models of work experience. The latter focuses on the interplay between the manifestation of knowledge in the contexts of education and work as well as learners' movement within and between both contexts. It differs from the connective typology, because it takes account of the mediated nature of the contexts of education and work as well as the process of learning through work experience. The chapter concludes by using the concept of recontextualisation to highlight how digital and mobile technologies could serve as resources to facilitate learning through work experience in schooland apprenticeship-based VET.
\end{abstract}

\section{Introduction}

The aim of this chapter is to compare two models of work experience and, in the process, identify their implications for the design and delivery of Vocational Education and Training (VET). The account of the first - the connective typology of work experience - is based on previously published work which was co-written with Toni Griffiths. This typology, which is based on the application of Weber's concept of ideal types to work experience, was constructed to: a) illustrate the way in which the assumptions made by educational institutions, employers and policymakers about the purpose of work experience influenced the design of each stage, phase and outcome of different models contained within the typology; and b) assist all parties involved with the planning and delivery of work experience to appreciate the significance of 
their role in facilitating learners to make connections between each of the different phases and stages. The term work experience was used in the typology to refer to the way that young people enrolled on both school- and apprenticeship-based VET learnt to relate their experience of education as represented by the acquisition of domain knowledge and their experience of work as represented by occupational values, skill and knowledge, to one another. It was acknowledged at the time however that the literature on apprenticeship tended to use the word - work - rather than work experience when describing apprentices' learning in the workplace. However, to provide a consistent lexicon in the typology, the term work experience was used to refer in both school- and apprenticeship-based VET to learners' experiences of the workplace. This lexicon has been maintained across the chapter to offer continuity with other contributors to this edited volume, though, the chapter explores in its conclusion why it is important to differentiate between work experience and work placement.

The second model - the recontextualisation of knowledge model - which is based on my recent work, is influenced by the Cultural-Historical Activity Theoretical argument presented in my book The Learning Challenge of the Knowledge Economy (Guile, 2010) that all cultural tools, in this case, forms of knowledge, are influenced by the purpose to which the tools serve. The model offers a way therefore to: (i) consider how forms of knowledge change as they are moved from their original context (discipline or workplace etc.) to become a part of curricula in educational institutions or occupational practice in workplaces; and (ii) workers and learners' engagement with curricula and occupational practice can, in principle, facilitate their integration into either an occupational form of knowing and practice or an awareness of different forms of occupational knowing and practice.

The common link between the two models is therefore that they accept the existence of a mediated relationship between education and work. The connective typology of work experience explores this relationship from a boundary crossing perspective, in other words, it focuses on learners' movement between education and work and identifies the outcomes associated with different models of work experience and, in doing so, took the contexts of education and work as a given. In contrast, the recontextualisation model focuses on the interplay between the manifestation of knowledge in the contexts of education and work as well as learners' movement within and between both contexts. In doing so, it takes explicit account of the mediated nature of the contexts of education and work as well as the process of learning through work experience compared with the connective typology. 
The chapter begins by firstly, outlining the way in which the 'knowledge' (OECD, 1995) and 'learning' (Sfard, 1998) debates in research and policy from the late 1980s and early 1990s influenced the formulation of the connective typology of work experience, before describing the way in which the five models of work experience contained within the typology offer learners access to different resources to integrate their experiences of education and work with one another. It then moves on to highlight a number of limitations associated with the typology and showing how the recontextualisation model was formulated to explicitly address those limitations and, in doing so, both retained and advanced the knowledge and learning debates which had been a significant influence on the formulation of the connective typology. Next, the chapter outlines the implications of the recontextualisation model of knowledge for work experience by discussing four different expressions of that process - context, pedagogic, workplace and learner - recontextualisation in relation to school-and apprenticeship-based VET. Finally, the chapter concludes by anticipating the future by using recontextualisation to highlight how digital and mobile technologies could be used as resources to facilitate learning through work experience in school- and apprenticeship-based VET.

\section{The connective model of work experience}

The 1990s were characterized by major debates in research and policy circles worldwide about: (i) the new role of knowledge in the economy via the concept of the 'knowledge economy'; and (ii) the relative merits of 'cognitive' versus 'situative' theories of learning. Both of these debates were, as will be explained below, significant influences on the formulation of the connective typology of work experience.

\section{The knowledge economy debate and its implications for work experience}

The initial interest in the relationship between economic and technological change and the increased role of knowledge in the economy originated in the sociological debates in the late 1960s and early 1970s about the transition from an industrial to a post-industrial society (Bell, 1973; Touraine, 1969), and culminated in the mid-1990s with the argument that information (Castells, 1996) or knowledge (Stehr, 1994) societies had superseded post-industrial societies. The common theme linking these slightly different interpretations about the continuing pace of economic and technological change was that: (i) scientific knowledge was now as central to all aspects of economic production, political regulation and most spheres of social and cultural life; and (ii) new sources of wealth were based upon the creative capacity of individuals and 
organisations to use scientific or theoretical knowledge innovatively. Thus, the sociological perspective on the knowledge economy took as axiomatic that codified knowledge had become central to the production of goods and services and was the primary condition for their further expansion as well as for the limits to economic growth.

This argument about the increased role of knowledge in the economy triggered throughout the 1990s a related debate about the contribution of knowledge to innovation. Innovation had traditionally been conceived of as an exogenous process driven by the application of highly abstract and codified forms of scientific knowledge developed outside the workplace (Stehr, 1994). A new claim about innovation now surfaced in, amongst other fields, Organizational Science, centred around the idea that a new economic and organisational imperative had emerged which placed enterprises under increased pressure to use their intangible assets (the knowledge and skills of their workforce) to innovate and create value for shareholders and customers (Nonaka \& Takeuchi, 1995; Spender \& Grant, 1996). From this perspective, innovation was both an exogenous and an endogenous process. It can be spurred through the exploitation of knowledge or information available inside enterprises to offer superior value in their traditional businesses and markets (Kim \& Mauborgne, 1998) as much as through the application of scientific knowledge. As a consequence, the challenge for workplaces from the organizational studies perspective was to build, combine and integrate the knowledge assets held by workplace communities to assist them to enhance their product and service delivery (Nonaka \& Teece, 2001).

The idea that all forms of knowledge now represented the primary source of wealth and innovation became in the case of the European Union, famously, coupled with lifelong learning in the European Memorandum on Lifelong Learning, and presented as the rationale for purpose of education and training polices (EU, 1999). One response to this development in EU Member States and other countries was to strengthen existing initiatives to support the transition of young people from school to work and to enhance their future employability. Two of the most common measures were to encourage schools to increase the opportunities for post-16 students to undertake work experience and to fund new educational programmes which include a work experience component for unemployed or disaffected young people (Griffiths et al., 2001). These initiatives tended, however, to rely on traditional assumptions about the role of work experience facilitating young people's transition to employment, for example, that an experience of work was sufficient to prepare learners for employment, rather than explicitly 
considering the way in which all parties involved in the design and delivery of work experience might have to collaborate to support learners to move between education and work to relate or integrate formal and workplace learning to one another (Guile \& Griffiths, 2001).

\section{The theories of learning debate and its implications for work experience}

The origins of, what became known as the 'cognitive' versus 'situative' (hereafter situated) debate in the Learning Sciences (see Sfard 1998 for a summary) lay in firstly, Jean Lave's book Cognition in Practice (Lave, 1988) where she developed a devastating critique of cognitive psychology for conceiving of: (i) the human mind as an attribute of an individual in isolation from the world; (ii) learning as the mastery of abstract representations taught in educational institutions in discipline-based curricula in the form of propositional statements; and, (iii) the transfer of learning as the application of propositions to practice. Secondly, Lave's subsequent book with Etienne Wenger Situated Learning (Lave \& Wenger, 1991) where they developed a theory of learning based on the notion of 'participation' in the routines and technologies of a 'community of practice' via access to 'learning curriculum', in other words, a sequenced and controlled way for less experienced workers - sometimes referred to as novices - to move from undertaking routine to novel tasks in workplaces, as a way to explain the simultaneous development of occupational expertise and identity in workplaces.

Inspired by the publication of Cognition in Practice and Situated Learning, a number of writers globally began in the 1990s to use the idea of a social theory of learning to analyse the forms of learning that occurred between education and work (see inter alia. Ainley and Rainbird, 1999; Billett, 2001; Evans, Hodgkinson and Unwin, 2002). One notable development was Beach's (1999) concept of 'consequential transition' (Beach 1999), which he explored empirically through reference to work experience (Beach and Vyas (1998). The main idea behind Beach's concept was that it stressed movement in relation to purpose and thus revealed how learners' knowledge and skill and identity may change as they undertake work experience. Four different types of consequential transitions - lateral, collateral, encompassing and mediational - were identified by Beach. The first and second pair referred to learners moving between sets of activities that are changing slowly compared to the changes that learners' experience as they move between them, for example, workplaces with well-established routines and learners who are feeling nervous, excited and challenged working in a new environment. The third and fourth pair referred to the rapid rate of change in an activity compared to the 
change that is required by the individual involved, for example, workplaces introducing new knowledge management practices which are as challenging for existing workers as they are for learners undertaking work experience.

To explain the relationship between movement and purpose in these different types of transition, Beach (1999) distinguished between the type of learning that occurred in education ('vertical development') and compared with the type of learning that occurs in workplaces ('horizontal' development'). The former referred to the way in which learners in schools engaged in the hierarchical acquisition of knowledge and skill through the apprehension of sets of concepts of ever greater abstraction or mastering higher levels of technical or craft-based skill. The latter referred to the way in which learners acquired forms of knowledge in curriculum contexts and this form of situated knowledge can take a variety of forms: it could be knowledge about how to participate in a community of practice, to change and vary work practices or to connect different fragments of codified knowledge to resolve work problems. It followed therefore from Beach's distinction, though he never pursued this issue, that for young people to benefit from work experience it was important for them to learn how to related their vertical and horizontal development and that both schools and workplaces had a pedagogic role in supporting this process.

\section{Connective typology of work experience}

To provide fresh thinking about the future design and delivery of work experience, a number of ideas, which had emerged from the debates about the new role of knowledge in the economy and the new social conception of learning, were used to formulate the criteria for a typology of work experience. The criteria were:

(a) the purpose of work experience (i.e. the reason for providing it);

(b) the assumptions about learning and development (i.e. the ideas about pedagogy and learning in workplaces);

(c) the practice of work experience (i.e. the types of practice which facilitate learning through work experience);

(d) the role of the education and training provider (i.e. the pedagogic strategies employed in vocational education to support students in learning);

(e) the outcome of the work experience (i.e. the form of knowledge, skill or broader capabilities that students have developed). 
The five criteria were constructed in the following ways. First, Beach's argument about the relationship between movement and purpose and the development of expertise and identity was extended to highlight the relationship between the purpose and outcome of work experience. Second, Lave and Wenger's argument that learning in workplaces entails participation in occupational practice, supported by access to learning curricula, was used to establish what was distinctive about the forms of learning that occurred in workplaces. The third combined insights from Beach and Lave and Wenger, for example, that learning is a back and forth movement between education and work which requires learners to vary their participation in both contexts by engaging dialogically with occupational practice, to draw attention to the pedagogic practices which facilitate the development of knowledge and skill through work experience. Fourth, Beach's distinction between vertical and horizontal learning was used to clarify the nature of the challenge that educational institutions and workplaces had to address if they were to support learners on academic and vocational programmes to integrate work experience with both forms of learning. Finally, the argument that all forms of knowledge (theoretical and practical) play a part in facilitating innovation in workplaces was used to affirm the aspirations of the EU Memorandum of Lifelong Learning that learners should be encouraged to identify knowledge and skills they had developed, irrespective of the context where they were learnt. This was a direct engagement with the EU's new interest in the Recognition of Prior Learning, that is, credit gained from study in a formal (i.e. educational institution) or non-formal (i.e. workplace training) context or Prior Experimental Learning, in other words, learning that occurred through participation in workplace or community activities. 
Figure 1. A typology of work experience

A typology of work experience (extended version)

\begin{tabular}{|c|c|c|c|c|}
\hline $\begin{array}{l}\text { MODEL OF WORK } \\
\text { EXPERIENCE }\end{array}$ & $\begin{array}{l}\text { Traditional } \\
\text { Model } 1\end{array}$ & $\begin{array}{l}\text { Experiential } \\
\text { Model } 2\end{array}$ & $\begin{array}{l}\text { Generic } \\
\text { Model 3 }\end{array}$ & $\begin{array}{r}\text { Work P } \\
\text { Mod }\end{array}$ \\
\hline $\begin{array}{l}\text { A. Purpose of work } \\
\text { experience }\end{array}$ & 'Launch' into work & $\begin{array}{l}\text { 'Co-development' } \\
\text { between education } \\
\text { and work }\end{array}$ & $\begin{array}{l}\text { Key skill/competence } \\
\text { assessment }\end{array}$ & $\begin{array}{l}\text { 'Attunement } \\
\text { environment }\end{array}$ \\
\hline $\begin{array}{l}\text { B. Assumption about } \\
\text { learning and } \\
\text { development }\end{array}$ & Adaption & $\begin{array}{l}\text { Adaption and self- } \\
\text { awareness }\end{array}$ & Self-management & Adjust and \\
\hline $\begin{array}{l}\text { C. Practice of work } \\
\text { experience }\end{array}$ & $\begin{array}{l}\text { Managing tasks and } \\
\text { instructions }\end{array}$ & $\begin{array}{l}\text { Managing } \\
\text { contributions }\end{array}$ & $\begin{array}{l}\text { Managing action plan } \\
\text { and learning } \\
\text { outcomes } \\
\text { PLUS } \\
\text { - managing situations }\end{array}$ & $\begin{array}{l}\text { Managing w } \\
\text { processes, re } \\
\text { and custome } \\
\text { PLUS } \\
\text { - adding valu } \\
\text { employer } \\
\text { - supportin } \\
\quad \text { employal }\end{array}$ \\
\hline $\begin{array}{l}\text { D. Management of } \\
\text { work experience }\end{array}$ & Supervision & $\begin{array}{l}\text { Arms-length } \\
\text { supervision }\end{array}$ & Facilitation & Coaching \\
\hline $\begin{array}{l}\text { E. Outcome of work } \\
\text { experience }\end{array}$ & $\begin{array}{l}\text { Skill acquisition } \\
\text { Knowledge of "work } \\
\text { readiness' }\end{array}$ & $\begin{array}{l}\text { Economic and } \\
\text { industrial awareness }\end{array}$ & $\begin{array}{l}\text { Assessed learning } \\
\text { outcomes }\end{array}$ & System think \\
\hline $\begin{array}{l}\text { F. Role of education } \\
\text { and training } \\
\text { provider }\end{array}$ & $\begin{array}{l}\text { Provide: } \\
\text { formal preparation } \\
\text { programme }\end{array}$ & $\begin{array}{l}\text { Facilitate: } \\
\text { briefing for and de- } \\
\text { briefing of work } \\
\text { experience }\end{array}$ & $\begin{array}{l}\text { Build: } \\
\text { portfolio of } \\
\text { achievements }\end{array}$ & $\begin{array}{l}\text { Support: } \\
\text { reflection-in } \\
\text { action }\end{array}$ \\
\hline
\end{tabular}


All the models contained in the typology were analytical rather than descriptive therefore no specific work experience programme necessarily fitted neatly into any of the models and some programmes may contain elements of more than one model. Nevertheless, the typology offered researchers, policymakers and practitioners a way to firstly, identify the contributions as well as the limitations of the first four models of work experience. This has been discussed widely in the apprenticeship or school-based VET literature, as regards to the development of learners' knowledge and skill as well as how work experience could be used to integrate education and work, and by extending theory and practice. Secondly, consider the difference that a new model - the connective model - could make for school-and apprenticeship-based VET if it became an integral feature at local, and even system, level in European countries.

\section{Bridge to Work Model}

The model is based on the classic 'launch' (Kindermann \& Skinner, 1992) assumption about the relationship between people and their environment, in other words, prior learning determines the trajectory of later learning, with the workplace environmental influence being viewed as fairly minimal. That assumption tended to underpin: a) traditional apprenticeship-based work experience programmes which were supposed to mold and adapt students' skills in the workplace through immersion in work practice, expressed colloquially as 'sitting by Nellie', though supported by the activities of a Meister (Vickers, 1995; Stern \& Wagner, 1999a, 1999b); and b) school-based work experience schemes which initially assumed that workplace knowledge, skills and attitudes were fairly transparent, rather than opaque, and that learners automatically assimilated them through observation and reproduction of routines and procedures (Watts, 1983). This perspective therefore took the integration of theory and practice for granted.

\section{Experiential Model}

This model reflected the argument, which had surfaced in many advanced industrial countries in the early 1990s that all stages and phases of education should be made relevant to learners through the introduction of either a problem-based approach or enquiry-based approach to teaching and learning (Prawat, 1993). This led to the relation between work and education being seen as a process of 'co-development' (Kindermann \& Skinner, 1992) which was supported, in the case of apprenticeship, by encouraging apprentices to try to integrate their experience of work and educational study by reflecting on those experiences in discussions with their trainers (Griffiths et al. 1991). In contrast, school-based work experience 
programmes tended to engage with the idea of co-development by using Kolb's (1984) 'experiential learning cycle' as a framework to support students to integrate their learning through work experience with their academic study (Jamieson et al., 1988; Miller et al., 1991). One outcome in the case of school-based VET was a recognition of the role played by intermediary agencies, such as education-business partnerships, in negotiating clear objectives for learners, workplaces and schools in advance of work experience (Griffiths et al., 1992). Another was the development of pedagogic practices to assist learners in identifying, possibly through the use of debriefing, the influence of work experience on personal and social development (Watts, 1991). These pedagogic practices were seen therefore to serve an integrative function.

\section{Generic Model}

The third model was a response to a slightly later educational debate that surfaced in Europe in the mid-to-late 1990s and which was concerned with promoting a greater sense of learner autonomy and self-discipline, particularly in low-attaining learners (Green et al. 1999). These developments led, in the UK in particular and, to a lesser extent, in other European countries, to the emergence of a generic perspective on learning, that is, the idea that a series of outcomes can be defined in the form of 'can do' or 'has learnt' or 'now understands' statements and that the process that facilitated such outcomes does not need to be defined (Griffiths et al. 2001). This perspective resulted in a model of work experience that: a) attached prime importance to the outcome and did not prescribe the learning necessary in a workplace to achieve that outcome; and b) accepted that an agreed series of common outcomes could be identified for any apprenticeship- or school-based VET programme of study and, therefore, it was possible to assess the learning that has occurred through study and work experience in the form of a key qualification (Kämäräinen \& Streumer, 1998).

This integration of education and work was taken forward through the introduction of personal action plan which served as a contract between the individual, the workplace and the educational institution by stipulating which skills were to be learnt; thus facilitating student self-assessment and external verification of key skill development in the form of learning outcomes within a workplace (Miller, 1996; Oates \& Fettes, 1997).

\section{Work Process Model}


This model emerged initially from within the German VET-apprenticeship tradition, but as a result of a large-scale EU funded research programme became a feature of apprenticeship in other EU countries (Boreham \& Fischer, 2002). The concept of work process knowledge (Arbeitsprozesswissen) - understanding the labour process in terms of product-related, labour organisational, social ecological and systems-related dimensions - was introduced to assist apprentices, workplace trainers and VET teachers to overcome the dilemma of inert knowledge, that is, knowledge which has been taught, but is not immediately useful for occupational practice (Kruse, 1996). From this perspective, the prime purpose of work experience is to help apprentices 'attune' (Kindermann \& Skinner, 1992) themselves to occupationally-specific knowledge and skill, for example, technical knowledge, knowledge of sector- or firm-specific systems and routines, and organizationally-general knowledge and skill, s such as product and service strategies. This model acknowledged that the development of work process knowledge had to be mediated through the introduction of subject knowledge which may occur within the workplace and company training centres (Attwell \& Jennes, 1996). The aim was to assist apprentices to integrate subject knowledge to current occupational practice by demonstrating the relevance of the former to the latter, and to position apprentices to engage with new organisational forms of production and thereby to move into alternative work environments more easily (Fischer \& Stuber, 1998).

\section{Connective Model}

This was an explicit attempt to construct a model of work experience based on an explicit articulation of the relationship between the different types of learning that occur in the context of education and work through shared pedagogic strategies. The model therefore acknowledged that for vertical and horizontal development to be integrated learners had to be supported to boundary cross, that is, move back and forth between education and work and this involved pedagogic challenges for educational institutions and workplaces. The term 'connective specialisation', that is, using the specialist knowledge and skill acquired in formal education in conjunction with their experience of work was invoked to encapsulate what was involved if learners were to integrate horizontal and vertical development. The challenge associated with connective specialization for: (i) educational institutions was defined as assisting learners to grasp the relationship between the theoretical concepts, which constitute the content of the educational programme they may be studying, and occupationally-specific and organizationally-general work practices and routines by explicitly probing their understanding of this relationship during de-brief sessions post-work experience; and (ii) workplaces was 
defined as ensuring that staff supervising learners on work placements provided time for learners to ask them questions about their participation in occupational practices and routines. The common challenge for educational institutions and workplaces was defined as agreeing on a mechanism whereby their feedback about their respective experiences to supporting work experience could be shared with one another, to support a process of the continuous improvement of work experience. The connective model therefore drew attention to the joint processes of learners' mulling over and deliberating, and experienced others (teachers, trainers etc.) facilitating that process of development through asking questions and offering additional commentary about work practice or the implications of theoretical concepts for practice and vice versa. In doing so, the model broadened the lexicon of integration. A line of thinking about the role of educational institutions and workplaces in supporting work experience has subsequently been elaborated and extended by Akkerman and Bakker (2011(a) (b)) in their work on boundary crossing.

\section{The recontextualisation model of work experience}

\section{Background to the model}

In the course of undertaking research on work experience in a variety of different settings, for example, apprenticeship (work- and college-based), Upper Secondary Education, and in different countries, for example, Denmark, Germany, Sweden, and the UK (Griffiths \& Guile, 2004), it became apparent that a number of the assumptions which underpinned the typology of work experience blurred the difference between apprentice- and school-based VET and between nature of knowledge-in-the-curriculum and knowledge-in-practice.

Firstly, by conceiving of school-based and apprenticeship-based VET as identical because both had an educational \& workplace component, the typology of work experience inadvertently treated work experience as a generic process to assist learners to grasp the theory-practice relationship. In doing so, it conflated learners who have educational as opposed to occupational goal when undertaking work experience into a single category of learner. This overlooked that work experience for the former is primarily an opportunity to learn about an occupational area and, in addition, appreciate the relationship between knowledge learnt in a classroom and its practical application in a workplace, whereas work experience for the latter is an opportunity to learn occupationally-specific knowledge and skill by grasping the manifestations of the theory-practice relationship through participation in occupational routines and procedures. 
Secondly, by leaving curriculum as an unexamined element within apprenticeship- and schoolbased VET, the typology implied that the concepts learners were taught in their curricula were coterminous with their manifestations in workplaces. In doing so the model overlooked that knowledge in workplaces is promiscuous; it runs across levels and areas and is embedded invisibly in workplace artefacts and routines. As a consequence, it is likely to be difficult for learners on either type of programme to understand the relationship between theory and practice when they were undertaking work experience, unless the pedagogic support they were offered explicitly recognised the promiscuity of knowledge.

The different outcomes from school- as opposed to apprenticeship-based work experience, coupled with preparing both types of learners to engage with the way in which knowledge is embedded in artefacts and routines, suggested that it would be more productive to focus afresh on the relationship between purpose, process and context, rather than redesign the typology to take better account of the above issues.

The recontextualisation model was therefore formulated to address the different manifestation of knowledge in educational institutions and workplaces and the implications of this difference for learning, rather than as a model of work experience per se. For this reason, the starting point was to identify how knowledge becomes: a) an embedded part of educational curricula and workplace practice and b) embodied in a worker as much as a learner through participation in educational and workplace pedagogic practices. The model is nevertheless informed by the same situated premise about knowledge and learning which informed the typology of work experience, in other words, that every type of human activity, for example, education, engineering, medicine, sport etc., is constructed and learnt contextually. The recontextalisation model differs from the typology because it draws on the argument about the constitution of, and continual development of, contexts which was presented in the book The Learning Challenge of the Knowledge Economy (Guile, 2010). That argument can be summarised as follows: contexts are constituted and continually revised culturally and historically through specialist forms of human activity, for example, education, engineering, pharmacy, and are therefore recognisable features of economic and social life; and, those features of economic and social life gain their unique character as individuals and groups work with and transform their normative conventions, routines and artefacts. The mediated relationship between the established and changing character of human activity was encapsulated in the concept of recontextualisation. The concept was subsequently elaborated and extended to distinguish between the different types of 
recontextualisation - content, pedagogy, workplace and learner - which are associated with the relationship between education and work as presented in Figure 2 below.

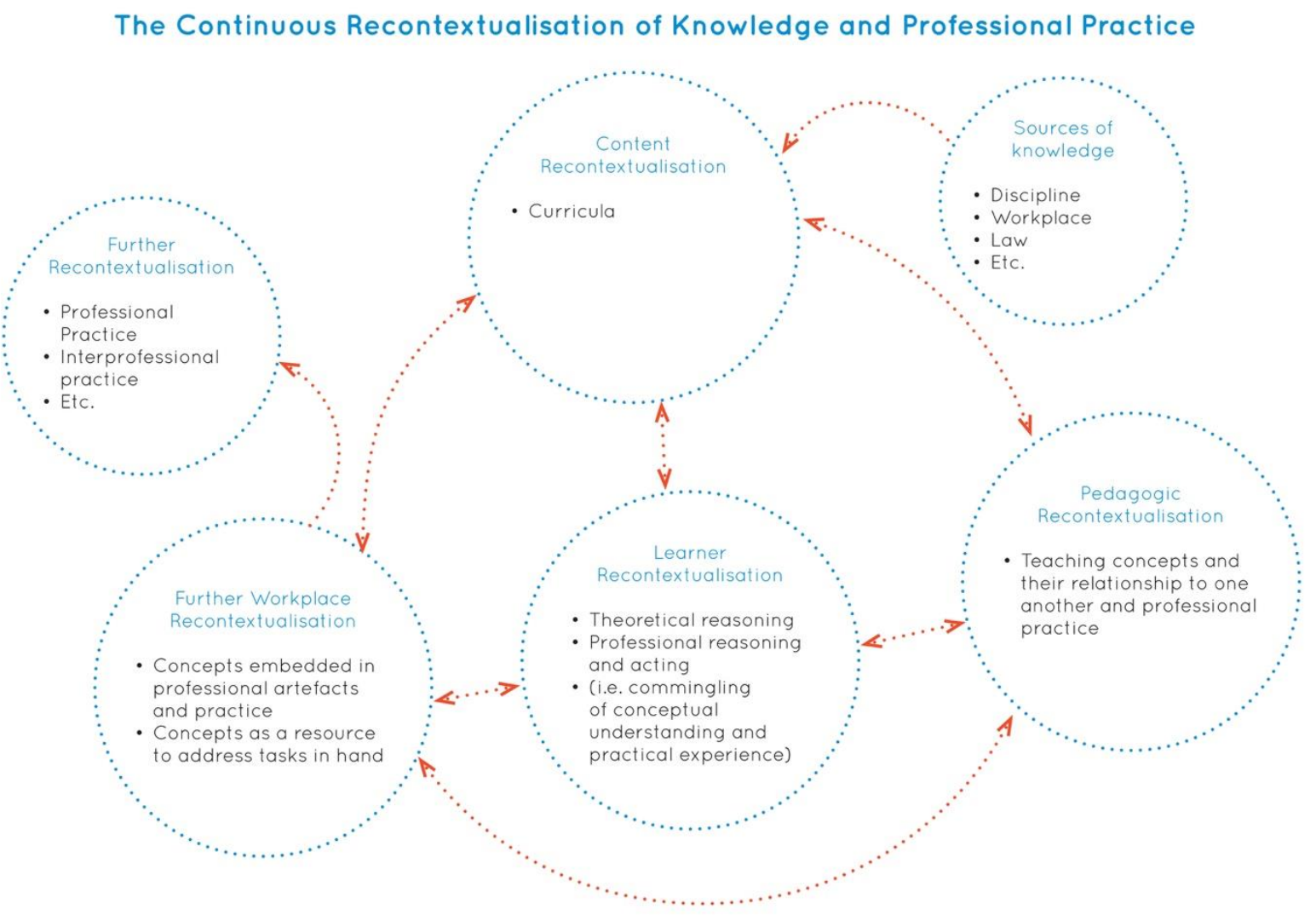

By distinguishing between these expressions of recontextualisation in the above model, it was possible to identify how firstly, the purpose of knowledge changes as it is moved from one context to another and secondly, workers moving from one context to another learn to engage with and re-embody the changing manifestations of the forms of knowledge they have already learnt (Guile, 2014). The implications of the different expressions of recontextualisation for understanding how people learn to engage with knowledge in educational institutions and workplaces have been explored empirically in studies of work experience in Pharmacy (Guile, 2014; Guile \& Ahmed, 2012), Internship in the Creative and Finance sectors (Lahiff \& Guile, 2016), and Engineering and Media Production (Guile (a) (b), forthcoming). The sections below therefore use issues raised in those studies to illustrate aspects of the model.

\section{The object of activity and recontextualisation}

The way in which forms of knowledge become part of curricula in education and routines and artefacts in work contexts was established in the book and articles referred to above through 
reference to Leont'ev's (1978) concept of the 'object of activity'. The idea that the object or purpose of an activity has a significant bearing on the way in which a) any activity is organised and b) the parties involved deploy resources - conceptual (i.e. forms of knowledge), material (i.e. technologies) and social (i.e. people) - to accomplish that activity, was used initially to distinguish between the role that forms of knowledge play in education and work. For example, it is generally agreed that, the role of domain knowledge in educational curricula is to introduce learners to disciplinary modes of thinking (Young, 2007) and the role of the domain knowledge in the professional education is to prepare learners for the transition to occupational practice (Young \& Muller, 2014), whereas the role of workplace knowledge is to facilitate the development of occupational practice (Lave \& Wenger, 1991), product and service development (Nonaka \& Takeuchi, 1995) and organizational and market strategy (Spender and Grant, 1996). The same domain knowledge could therefore, from time to time, be serving a different purpose. In light of this the above model makes a distinction between content and workplace recontextualisation, that is, the way in which the same domain knowledge becomes a resource for education or work through being embedded in curricula or workplace artifacts and practice.

The first term (content) refers to the way in which the parties involved in curriculum planning, such as, universities, professional associations etc., formulate criteria to determine the different forms of knowledge, such as, disciplinary, professional/legal, work-based, that should be included and sequenced in curricula. The process and outcome of content recontextualisation is, however, rather different in academic compared with vocational curricula. The purpose of an academic curricula is to immerse learners into specific disciplines and disciplinary ways of reasoning whereas the purpose of a vocational curricula is to support the formation of occupational expertise and identity. Thus it follows that, to borrow Bernstein's (2000) terminology, concepts are 'classified', 'framed' and 'sequenced' in academic curricula to support learners to ascend through disciplinary 'knowledge structures' and to develop disciplinary modes of reasoning. In contrast, the purpose of a vocational curricula is to prepare learners for a vocation or an occupation by assisting them to see the relationship between disciplinary concepts and their practical application in workplaces by developing learners' occupational mode of reasoning (this is often referred to as practical reasoning). Expressed differently, the same concepts serve different purposes in academic and vocational curricula.

The above issue can be illustrated by, for example, comparing the reason for including the concept of 'genre' in an academic subject, such as English with its inclusion in a vocational 
programme of study, such as Media Production (Lahifff \& Guile, 2016). The purpose of the concept of genre, in the case of the former, is to assist an academic learner to understand debates in Literary Theory about, for instance, the development of, and even the intersection of, different forms over time. Whereas in the case of the latter, it is to assist a vocational learner, for example, an apprentice to understand the difference between types of television and radio programmes and the way in which the production team work collaboratively create the appropriate mood, including the language music, lighting, for each type of programme.

The pedagogic challenge of content recontextualisation can be illustrated, as (Guile \& Ahmed, 2013) have observed, through reference to the different role that knowledge domains play in an academic compared to vocational curricula. Using the example of Pharmacy, Guile \& Ahmed focus on the role of Organic Chemistry and Molecular Biology in a Pharmacy degree, in comparison to their role in a Chemistry or Biology degree (Guile \& Ahmed, 2013). The reason for the inclusion of Organic Chemistry and Molecular Biology, in the case of the former, is to assist aspiring pharmacists to understand all aspects of Pharmacology whereas, in the case of the latter, it is to support learners to understand the development of the respective discipline as well as to prepare them to specialise in the fields of Organic Chemistry and Molecular Biology. The critical issue is therefore to devise a pedagogy to support learners to understand Organic Chemistry and Molecular Biology in ways that are consistent with the degree they are a part of.

Workplace recontextualisation refers to the way in which professionals working in organisations have embedded and continue to embed different forms of knowledge in workplace routines and artefacts as well as to their engagement with, and embodiment of, those forms of knowledge. One way to illustrate this issue is through reference to the role of SemiConductors in an Electrical Engineering degree. To understand the way in which a semiconductor functions learners will typically be taught, amongst other issues, about the way in which Electron Construction Bands (ECBs) flow through different materials. Electron Construction Bands are however ubiquitous in workplaces, almost to the point where they disappear because they are an embedded feature of, for example, IT systems. Professional electrical engineers are, inevitably, aware that IT systems could not operate without ECBs; but merely take them for granted as part of the workplace environment and when monitoring or repairing an IT system operate with an embodied rather than explicit understanding of ECBs. Workplace recontextualisation of engineering concepts, such as ECBs masks, therefore the way in which that concept is contributing to the effective operation of IT systems. 
This poses a problem for a student electrical engineer or a student who is studying physics at an advanced level, prior to choosing which degree they may undertake at university, when they undertake work experience. Either type of student would struggle to establish any visual or tactile relationship between the theory of ECBs they had been taught and the practical manifestation of that theory in a workplace artifact such as an IT system. Furthermore, they would not necessarily find listening to professional electrical engineers' everyday conversations with one another helpful in illuminating the operation of ECBs in IT systems, because they are probably rarely, if ever, explicitly referred to. As a consequence, a learner undertaking a work placement is more likely to focus on the visible nature of engineering work because it affords them a way to participate in workplace conversations. Making the forms of knowledge, such as ECBs that are embedded in workplace artifacts and practices explicit involves that learner acting agentically by either inferring for themselves the role of ECBs in IT systems or asking professional electrical engineers to explain the way in which they support the effective performance of an IT system.

The common pedagogic link therefore between academic and vocational pedagogy is that learners are supported to develop a capability to infer what follows from either their study or their study and work experience.

\section{The role of giving and asking for reasons (inferring) and recontextualisation}

The implications of the embeddedness of knowledge in educational curricula and workplaces was explored in The Learning Challenge of the Knowledge Economy and the articles referred to earlier through reference to Brandom's (2000) concept of learning as an inferential social practice based on the giving and asking for reasons. This concept of learning is, as was explained in the above book, consistent with the CHAT assumption that what is distinctive about human activity is that we are susceptible to reasons and act in accordance with those reasons, in other words, we develop the capability to recognise the normativity of life. For example, when we hear a command, such as 'get out of the way', we understand its potential implications that we could be about to be knocked over or to become involved in an argument with someone if we respond aggressively to that command. From this perspective, we develop the capability to understand what different types of oral or textual communication may refer to as we learn to give reasons for our beliefs or actions, ask others for the reasons for their beliefs or actions, 
and infer what follows from the different reasons that are given in different contexts. The model therefore invoked the term pedagogic recontextualisation to refer to the way in which people grasp and relate reasons between educational and workplace contexts.

One way to highlight this different outcome is to contrast pedagogic recontextualisation in the study of, the practice of being, a pharmacist and the use of work experience for a student considering studying pharmacy at university. The purpose of pedagogy is, in the case of the former, to support pharmacy students studying in a university to develop a disciplinary mode of reasoning, but when they are undertaking work experience an occupationally-specific mode of reasoning, in other words the capability to discriminate things that follow and things that do not and what would count as evidence and what would not, in both contexts. The former involves, at a minimum, the capability to: a) understand the conceptual structure of a discipline; b) to locate a concept in its sub-field within the discipline; c) infer relationship from that concept to other concepts; and d) express that disciplinary form of reasoning in written form. In contrast, the latter involves, at a minimum, the capability to: a) understand the way in which different forms of knowledge are embedded in the work process and workplace artefacts; b) use that understanding to work with other professionals to produce products and services; and c) draw on resources external to the workplace, when necessary, to resolve problems.

The process of pedagogic recontextualisation is predicated on lecturers supporting learners to grasp the relationship between theory and practice by assisting them to infer: (i) relationships between concepts they are studying as part of their university course, in other words, their links to one another; and (ii) what follows between concepts and professional practice, in other words, how they mutually inform one another.

The implications of this observation can be highlighted by considering Systemic Pharmacology, that is, the action of drugs on physiological systems, which is one of the subareas in pharmacy that would be taught to pharmacy students to help them to develop both discipline-based and occupationally-specific reasoning. By being encouraged to understand the pharmacological basis of medicines and the way in which drugs affect biological systems, pharmacy students are positioned to undertake a work placement where they are likely to have to assess the benefits for patients that arise from one drug compared with another one as well as anticipate typical patterns of Adverse Drug Reactions (ADRs) or idiosyncratic reactions that may occur in patients. 
When undertaking work experience as part of their Pharmacy Degree, student pharmacists will however encounter patients who frequently have multiple conditions and complex medical histories. Determining the likelihood of an ADR in a patient is therefore a complex and challenging process for a student pharmacist, even though they will be supported by an experienced pharmacist, because they have to firstly, recontextualise their knowledge of Systemic Pharmacology and patterns of ADRs in relation to: (i) a patient's description of their particular condition and any previous ADRs they may have experienced; (ii) the available medicines which may be appropriate for the patient's condition; and (iii) the advice an experienced pharmacist is offering them about likely ADRs in relation to the patient's medical history, in order to decide which medicine to recommend to the patient. The outcome of this workplace pedagogic recontextualisation is the gradual development of a student pharmacist's occupational mode of reasoning based on their capability to form judgements by inferring what follows in relation to a patient's context-specific circumstances. In contrast, students undertaking a work placement in a pharmacy to help them to decide whether to study pharmacy at university are still interested in reasons; but a different set of reasons. They will focus on why the pharmacists chose this career and why it is professionally rewarding or challenging. They are also engaged in a process of workplace recontextualisation but where the purpose is to facilitate a career decision rather than the development of occupationally-specific expertise.

The three forms of recontextualisation - content, pedagogic and workplace - described above all contribute to, but do not, as the model presented earlier indicated, determine the formation of learners' expertise and identity. This process is completed as learners simultaneously exercise their agency to engage with the opportunities provided in educational institutions and workplaces as well as to create opportunities for themselves, to develop their capability to reason in disciplinary and occupationally-specific ways. In doing so, learners commingle their own object of activity, that is, their reason for undertaking the work experience with their workplace experiences to identify or choose an alternative career direction.

The outcome of the process of learner recontextualisation varies according to whether a learner is enrolled on an academic or vocational programme of study, even though they both provide access to work experience, and in relation to the different forms of assessment they are subject to, Learners are expected, in the case of the former, to express their understanding in written and oral forms in accordance with disciplinary conventions, warrants and modes of assessment, 
and to use work experience as a way to learn about an occupation or a sector or to help them to make a career choice. In contrast, vocational learners are expected to express their understanding in written and oral forms in accordance with similar conventions and modes of assessment, but to also use their work experience to commingle disciplinary and practical understanding and experience to develop an occupational form of knowing. Returning to the example of Systemic Pharmacy, a student pharmacist is expected to develop both types of reasoning: their class of degree will be judged by their ability to reason in accordance with discipline-specific assessment criteria while their performance in pharmacy practice will be judged by their capability to reason and act in occupationally-specific ways.

\section{Facilitating recontextualisation through digital and mobile technologies}

This chapter had one main aim - to compare the Connective Typology of Work Experience with the Recontextualisation Model of Knowledge and its implication for work experience by showing how the latter addresses the limitations of the former and, in the process, offer researchers, policymakers and practitioners ways to distinguish, rather than conflate, the different learning outcomes associated with school- as opposed to apprenticeship-based VET. It concludes by pursuing this issue through a discussion of the role of digital and mobile technologies in work experience for both types of VET.

There is widespread acceptance that the expansion of digital technologies provides learners with opportunities to access and undertake learning activities in a range of other settings, including home, college and workplace environments, public libraries and youth centres (see for an up to date overview, Ludvigsen et al. 2011). Devices such as computers, laptops, mobile phones and netbooks have contributed to the development of the virtual learning space where learning might not be associated with a specific site or specific time, but there has been less discussion of how the above technologies and forms of mobile learning offer educational institutions and workplaces new ways to enhance work experience in school- and apprenticeship-based VET.

To illustrate their potential, the chapter firstly draws on Wishart and Green's (2011) notion of 'mobile scenarios' for the future to identify a number of ways in which learners could use digital and mobile technologies to facilitate boundary crossing between education and work. It 
then uses the recontextualisation model to consider the implications of each scenario for school- and apprenticeship-based VET. Wishart and Green's scenarios are:

- Scenario 1. Recording experiential learning in a vocational area in preparation for a placement-colleges could ensure that learners create their own portfolios, which could be accessed by mobile phones, for instance an Internet café etc., while learners are studying with them. This resource would have both a private and public space: the latter would contain a learners' photographs, videos, video diary reflections of occupationally-specific learning while the former would contain their course materials, assignments and assessments, via a Virtual Learning Environment and so forth.

The creation of on-line portfolios would enable learners, at a later date, to use aspects of their experiential learning for peer discussions, a resource for assignments, and for inclusion as part of their shared professional portfolio in public networks such as, LinkedIn.

- Scenario 2. Working and learning together on placements (i.e. work experience) handhelds or mobile laptops could be used by learners to share their experiences, reflections with their peers and tutors whilst they are on placement.

Learners could use handheld devices to work on the same or similar problems to liaise with one another and discuss how they were tackling the same problem, and tutors could organise Skype discussions between themselves and learners on placements to discuss converging and diverging experiences.

- Scenario 3. Connecting services and resources - colleges, in conjunction with their libraries, can arrange for learners to have remote access to books, periodicals, databases etc. which can be accessed whilst studying away from colleges or on work placement.

Ubiquitous connectivity would enable learners to revisit course content while on placement and use it as a resource to help them to address the workplace embeddedness of knowledge, and/or to post questions that other learners on a work placement or their tutor could answer.

From the recontextualisation perspective presented in this chapter, the purpose of VET programmes will influence the way in which learners both engage with digital and mobiles technologies and the type of knowledge and skill they will develop. For example, learners on school-based VET will use the digital and mobile technology possibilities described above to 
share their experience of their work experience with one another to: (i) reveal the diversity of work in an occupational area; (ii) generate discussions about the problem of the embeddedness of knowledge; (iii) involve other learners and their tutor in a discussion about the range of tasks they have been given to attune them to working a specific occupational area; and (iv) develop a LinkedIn portfolio to promote themselves to a potential employer. In contrast, learners on apprenticeship-based VET will share their experience of their work experience with one another to: (i) discuss the extent to which they are or are struggling to develop occupational expertise; (ii) generate discussions about how to resolve the problem of the embeddedness of knowledge; (iii) involve other learners and their tutor in a discussion about the way in which curricula content and workplace practice might be aligned more closely; and (iv) create a LinkedIn portfolio to identify the range of occupationally-specific knowledge and skill they have acquired for their current and, potentially, future employer.

The purpose of mobile learning is therefore, from the recontextualisation perspective, about the processes of coming to know and being able to operate successfully in and across new and ever-changing contexts, learning spaces and boundaries, rather than delivering content to mobile devices. The brief sketch provided at the end of this chapter will hopefully offer researchers and practitioners a way to reconsider how to support learners to use work placements to boundary cross within as well as between educational curricula and work practice. 
Akkerman, S. F., \& Bakker, A. (2011). Boundary crossing and boundary objects. Review of Educational Research. 81 (2): 132-169.

Akkerman, S. F., \& Bakker, A. (2012). Crossing boundaries between school and work during apprenticeships. Vocations and Learning. 5(2), 153-173.

Beach, K. Consequential transitions: A sociocultural expedition beyond transfer in education. Review of Research in Education, 1999, Vol. 24, pp. 101-139.

Beach, K. (1999). Consequential transitions: A sociocultural expedition beyond transfer in education. Review of research in education, 24, 101-139.

Beach, K.; Vyas, S. Light Pickles and Heavy Mustard: Horizontal development among students negotiating how to learn in a production activity. Paper presented at the Fourth Conference of the International Society for Cultural Research and Activity Theory, June 1998 University of Aarhus, Denmark.

Beach, K. \& Vyas, S. (1998) Light Pickles and Heavy Mustard: Horizontal development among students negotiating how to learn in a production activity, paper presented at the Fourth Conference of the International Society for Cultural research and Activity Theory, University of Aarhus, Denmark.

Bernstein, B. (2000), Pedagogy, Symbolic Control and Identity: Theory, Research and Critique (Revised Edition). Lanham: Rowman and Littlefield.

Bell, D. (1973). The Coming of the Post Industrial Society. New York: Basic Books.

Billett, S. (2001) Learning in the workplace. Sydney: Allen and Unwin.

Billett, S. (2001). Learning in the workplace: Strategies for effective practice. Allen \& Unwin, PO Box 8500, St Leonards, 1590 NSW, Australia.

Boreham, N. \& Fischer, M. (2002) Work Process Knowledge. London: Routledge.

Brandom, R. (2000) Articulating reasons: An introduction to inferentialism. Cambridge. MA: Harvard University Press.

European Union, Lifelong Learning Memorandum. Brussels: EU, 1999.

Fischer, M.; Boreham, N. (2004) (eds). European perspectives on learning at work: the acquisition of work process knowledge. Thessaloniki: Cedefop.

Fischer, M.; Stuber, F. Work process knowledge and school-to-work transition In: Scherer, E. (ed.). Shop Floor Control: A Systems Perspective. Berlin: Springer Verlag, 1998. 
Fischer, M., \& Stuber, F. (1998). Work-process knowledge and the school-to-work transition. In Shop Floor Control-A Systems Perspective (pp. 367-380). Springer Berlin Heidelberg.

Fischer, M. (2001) Work process knowledge in the context of socio-technical innovation. Proceedings of the European Conference on Educational Research, Lille, 2001.

Green, A., Leney, T. \& Wolf (1999) Convergence and Divergence in European Education and Training Systems, London: Bedford Way Papers, Institute of Education, University of London

Griffiths, T, Miller, A \& Peffers, J, eds. (1992) European Work Experience: Principles and Practice, Centre for Education and Industry: University of Warwick,

Griffiths, T. \& Guile, D. (1999) Pedagogy in work-based contexts. In: Mortimore, P. (ed.). Understanding pedagogy and its impact on learning. London: Sage Publications

Griffiths, T. et al. (2001) Work experience as an education and training strategy: new approaches for the $21^{\text {st }}$ century. Final report of an EU Fourth Framework (Targeted Socio-Economic Research) project to the European Commission.

Guile, D. \& Griffiths, T. (2001). Learning through work experience. Journal of Education and Work, 14(1), 113-131.

Guile, D. (2014). Professional knowledge and professional practice as continuous recontextualisation: a social practice perspective. In Muller, J. and Young, M. (Eds), Knowledge, expertise and the professions. London: Routledge, pp.78-92.

Guile, D. (2014 (b) Professional knowledge and professional practice as continuous recontextualisation: a social practice perspective in Fenwick, T. and Nerland, M. (ed) Rethinking Professional Learning. London: Routledge.

Guile, D. (2011) Apprenticeship as a model of vocational 'formation' and 'reformation': the use of Foundation Degrees in the Aircraft Engineering Industry, Journal of Vocational Education and Training Vol 63 No 3 pp: 451-464

Guile, D. (2010) The Learning Challenge of the Knowledge Economy. Rotterdam: Sense.

Guile, D. \& Ahamed, F. (2010) Modernising the Undergraduate Pharmacy Curriculum. LLAKES Research Paper 26. ESRC Research Centre Learning and Life Chances in Knowledge Economies and Societies, Institute of Education, University of London.

Jamieson, I., Miller, A. \& Watts, A.G. (1988) Mirrors of Work. Brighton: Falmer Press.

Kämäräinen, P. Alternative Strategies for Parity of Esteem between General/Academic and Vocational Education in Europe. In: Lasonen, J. (ed.). Reforming Upper Secondary 
Education in Europe. Institute for Educational Research, University of Jyväskylä, 1997.

Kämäräinen, P. \& Streumer, J. (1998) Curriculum development, new learning environments, and transfer of innovations in Europe. Vocational Education and Training - the European research field. Background Report 1998, Vol. II. Thessaloniki: Cedefop.

Kindermann, T. and Skinner, E.A. (1992) 'Modeling environmental development: individual and contextual trajectories' in Asendorpf, J.B. and Valsiner, J., eds., Stability and change in development London: Sage

Kolb, D. Experiential Learning. Englewood Cliffs: Prentice Hall, 1984.

Lahiff, A. \& Guile, D. (2016) "It's not like it's normal 9 to 5" : the learning journeys of media production appremtices in distributed working conditions, published on-line Journal of Vocational Education and Training

Lasonen, J. in Attwell, G. European policy studies of work experience based on fieldwork and conversations with scientific experts in European countries. http://www.theknownet.com/cedra, 2000. Field report prepared for Griffiths, T. et al. Work experience as an education and training strategy: new approaches for the $21^{\text {st }}$ century. Final report of an EU Fourth Framework (Targeted Socio-Economic Research) project to the European Commission, 2001.

Lave. J. \& Wenger. E. (1991) Situated learning: legitimate peripheral participation. New York: Cambridge University Press.

Lave, J. (1988) Cognition in practice: Mind, mathematics and culture in everyday life. Cambridge: Cambridge University Press.

Miller, A. (1996) To boldly go ... work experience but not as we know it? In: Miller, A.; Forrest, G. (eds). Work experience for the $21^{\text {st }}$ century. CEI: University of Warwick.

Miller, A., Watts, A.G. \& Jamieson, I. (eds) (1991). Rethinking Work Experience. Brighton: Falmer Press.

Nonaka, I. \& Takeuchi, H. (1995) The Knowledge Creating Company. New York: Oxford University Press.

Nonaka, I. \& Teece, D. (2001) Managing Industrial Knowledge. London: Sage.

Oates, T. \& Fettes, T. (1997) Work experience and key skills. In: Forrest, G. (ed.) Work experience for the $21^{\text {st }}$ century: changing priorities, changing practice. CEI: University of Warwick.

Prawat, R. (1993) The value of ideas. Educational Researcher, 
Sfard, A. (1998). On two metaphors for learning and the dangers of choosing just one. Educational researcher, 27(2), 4-13.

Spender, J. C., \& Grant, R. M. (1996). Knowledge and the firm: overview. Strategic management journal, 17(S2), 5-9.

Stehr, N. (1994) Knowledge Societies. London: Routledge,

Stern, D. \& Wagner, D. A. (eds) (1991a). International Perspectives on School-to-Work Transition. Cresskill N. J.:Hampton Press.

Touraine, A. (1969) Post Industrial Society. New York: Random House,.

Vickers, M. (1995) Employer Participation in School-to-Work Programmes: The Changing Situation in Europe. In: Bailey, T. (ed.). Learning to Work: Employer participation in school-to-work programmes. Washington, DC: Brookings Institute.

Watts, A.G. (1991)The concept of work experience. In: Miller, A.; Watts, A.G.; Jamieson, I. (eds). Rethinking Work Experience. Brighton: Falmer Press.

Watts, A.G. (1983) Work Experience and Schools. London: Heinnemann.

Wheelehan, L. (2010) Why Knowledge Matters in Curriculum. London: Routledge. 